\title{
ISTORINIO JĖZAUS PĖDSAKAIS: PONCIJAUS PILOTO ATVEJIS
}

\author{
Arvydas Ramonas \\ Klaipèdos universitetas
}

\begin{abstract}
Anotacija
Straipsnyje analizuojamas istorinis Jèzaus iš Nazareto gyvenimo ir veiklos kontekstas, jame - ir Poncijaus Piloto asmuo. Krikščioniu tikejjimo centre visada buvo ir yra Jèzaus Kristaus figūra. Tad kristologija teologijos studijose užima svarbia vietą. Jokios teologinès studijos nebus išsamios, nepabandžius giliau pažvelgti ị Jèzu Kristų. Visais amžiais kristologijai teiktas ypatingas dèmesys, pastarujų dešimtmečiu, ypač XX amžiaus antrosios pusés, studijos ypač akcentuoja Jėzaus Kristaus istorinị asmenị ir jo konteksta, kuriama aptinkama ịvairiu istoriniu asmenų. Tarp jų - ir Poncijus Pilotas. Šis Romos imperatoriaus vietininkas valde Palestina kaip tik tuo metu, kai joje gyveno ir veike Jėzus Kristus. Pateko ị istorija kaip vienas iš Jo teismo proceso dalyviu, bandžiusių iš pradžiu išteisinti Jèzu, bet galiausiai jị pasmerkusiu ir ,„žydu rankomis" pražudžiusių.

PAGRINDINIAI ŽODŽIAI: Jèzus Kristus, istorija, Poncijus Pilotas.
\end{abstract}

\begin{abstract}
The article analyses the historical context of the life and activities of Jesus of Nazareth, and includes the person of Pontius Pilate. At the centre of the Christian faith has always been and is the figure of Jesus Christ. Therefore, Christology occupies an important place in theological studies. No theological study will be complete without a deeper look at Jesus Christ. Christology has received particular attention throughout the centuries, but studies over the last few decades, especially in the second half of the twentieth century, place particular emphasis on the historical person and context of Jesus Christ. In this context, various historical figures are found. This includes Pontius Pilate. This deputy of the Roman emperor ruled Palestine at the very time when Jesus Christ lived and acted in it. He entered history as one of his participants in the trial, initially trying to justify Jesus, but eventually condemning him and perishing with the "Jewish hands".

KEY WORDS: Jesus Christ, History, Pontius Pilate.
\end{abstract}

\section{Ivadas}

Pagrindinis informacijos šaltinis apie Jėzaus iš Nazareto viešaji gyvenimą yra Šventasis Raštas, ypač keturios Evangelijos, Pauliaus laiškai ir pan., 
kitaip tariant, krikščioniški šaltiniai. Kitų istorinių šaltinių (ne biblinių) yra nedaug. Iš pradžių Evangelija skelbta žodžiu, ji nebuvo labai įdomi ar patraukli, tai iš dalies galima paaiškinti tuo, kad šiuo laikotarpiu hebrajai nelabai vertino raštą, nes kultūra buvo verbalinè. Tik nuo II a. padaugèjo istorinių šaltinių, bet jie labiau susiję apskritai su krikščionybe, o ne su Jėzaus asmeniu.

Vienu tokių šaltinių galima laikyti pagonių filosofo Celso krikščionybès kritiką, ị kurią reaguodamas Origenas sukūrè savo apologetiką (Penna, 2004, p. 49). Tekstų, kur būtų rašoma tiesiogiai apie Kristų, I-II a. yra mažai. Visų pirma tai apokrifai: egzistuoja dar maždaug dešimt evangelijų, kurios yra nekanoninès, paprastai tariant, neistorinès, netikros. Prie tokių apokrifų priskiriami ir vadinamieji „Piloto darbai“. Tai bandymas sistemiškai išdėstyti šio Romos imperatoriaus vietininko Palestinoje darbus. Iš rimtesnių istorinių šaltinių dėmesio vertas žydų istoriko Juozapo Flavijaus tekstas „Žydų senove““, kuriame užsimenama apie Jèzų iš Nazareto ir Joną Krikštytoją. J. Flavijus nebuvo atsivertęs ị krikščionybę, tad, jei savo ataskaitoje mini šiuos asmenis, jiems teikè istorinę reikšmę. Visiškai atsitiktinai Kristų savo „Analuose“ pamini Kornelijus Tacitas. Jis buvo Romos imperijos metraštininkas ir rašydamas apie tai, kaip Neronas padegė Romą, užsimena apie Pilotą ir tai, kaip imperatorius kaltę dèl padegimo suvertė Kristaus sekèjams (Sanders, 1999, p. 63). Poncijų Pilotą mini ir Juozapas Flavijus bei Filonas iš Aleksandrijos. Dar apie Kristų trumpai užsimena Svetonijus, Plinijus Jaunesnysis, rašęs apie ano meto Bitinijos krikščionis. Jėzaus vardas paminėtas žydų „Babilonijos Talmude“ (Pie-Ninot, 2002, p. 346-351). Reikia pripažinti, kad beveik nèra patikimos informacijos apie ankstyvaji Jèzaus gyvenimo laikotarpi, ypač jo vaikystę. Tai paaiškinama tuo, kad pirmiesiems Evangelijos skelbejjams istorinis kontekstas nelabai terūpejo, tik Jèzaus figūra: Atpirkèjas, Išganytojas, Mokytojas ir pan. Kitaip tariant pirmuosiuose amžiuose skelbiant Evangeliją akcentuota soteriologija (išganymas), o ne istoriografija (kaip tiksliai gyveno Jèzus Nazarietis). Tačiau šiandien vis labiau gilinantis ị ano meto judaizmo kultūrą, visą ano meto kontekstą, atrandama ịdomių archeologinių, istorinių žinių apie kitus asmenis, pavyzdžiui, Erodą, Poncijų Pilotą, esenų bendruomenę, kuriai galbūt priklausẻ Jonas Krikštytojas ir visa eilè kitų. Pavyzdžiui, Poncijų Pilotą Rytų Stačiatikių Bažnyčia, ypač koptų ir etiopų, pripažista 
kaip pozityvų asmeni, t. y. vos ne šventaji, kuris bandè išgelbèti Jėzų nuo tragiškos mirties. Vakarų (Romos) krikščionybèje paprastai manoma, kad jis yra neigiamas asmuo, bailys ir žydų religinès valdžios pataikūnas, nekaltai nuteisęs Jėzų. Kad Pilotas nebuvo nuožmus valdytojas patvirtina ir naujausi archeologiniai, istoriniai tyrinėjimai. Nors apie jị tikrai labai mažai duomenų, kažkiek faktų paminèti galima.

Straipsnio objektas - istorinis Jézus ir Poncijus Pilotas.

Straipsnio tikslas: išnagrinèti istorinị-kultūrinị I a. kontekstą, atskleisti Poncijaus Piloto svarbą Jėzaus tragiško likimo pabaigoje.

Darbo uždaviniai:

1. Glaustai apžvelgti Biblijos kristologinius metmenis.

2. Pristatyti Jėzaus iš Nazareto kultūrinị judaizmo kontekstą.

3. Atskleisti Poncijaus Piloto vaidmenị Jėzaus gyvenimo, bet ypač mirties, istoriniame kontekste.

Metodai: Šventojo Rašto hermeneutika, mokslinès teologinès literatūros analizè, interpretacija, sintezè.

\section{Istorinio Jèzaus studijos}

Istorinis Jėzus iš Nazareto visada domino krikščionis ir ne tik - ateistus ir šiaip besidominčiuosius religija. Šiuolaikiniame moksle neabejojama, kad šis asmuo išties gyveno, bet vis dar lieka neatsakytas klausimas apie jo istorini kontekstą, sąlytị su judaizmu, tikrąsias išganymo intencijas. Taip yra todèl, kad kituose šaltiniuose, be kanoninių Evangelijų, apie Jėzų iš Nazareto, kaip minèta, labai mažai kalbama. Kaip žinia, Evangelijos yra jau tikẻjimo „nuspalvinti“ tekstai, t. y. parašyti su labai aiškia intencija - pristatyti Jėzų Kristų kaip Dievo Sūnų, Mesiją, Išganytoją ir Viešpatị. Visai tai peržengia vien tik istorinio asmens ribas, nes norima papasakoti apie dievažmogi, koks šis asmuo ir buvo.

Pernelyg neišsiplèsdami glaustai paanalizuokime pastarojo šimtmečio pastangas ,pasiekti““ istorinị Jèzų. Iškart po Antrojo pasaulinio karo teologijos ir biblistikos mokslų dèmesys buvos skiriamas Jėzaus, Pauliaus ir kitiems Biblijos personažams. Istorinis Jėzus imamas sieti su skelbiamu ir tikimu, išpa- 
žịstamu Kristumi. Pasirodè Reformuotosios Bažnyčios teologų Karl'o Barth'o ir Rudolf'o Bultmann'o veikalai. K. Barth'o teigimu, apie Kristų žinome tik tikèdami. Tuo tarpu R. Bultmann'as teigè, kad mes beveik nieko negalime žinoti apie Jèzaus gyvenimą ir jo asmenį, tad teologija turètų susitelkti ne tiek ties Jėzaus viešuoju istoriniu gyvenimu, kiek ties kryžiaus skelbimu, t. y. tik ties povelykinès tikinčiujų bendruomenès išpažįstamu Kristumi, kuris per kryžių atpirko žmoniją iš nuodèmių. 1953 m. R. Bultmann'o mokinys Ernest'as Kasemann'as vienoje iš savo paskaitų pateikè istorinio Jėzaus „naują klausimą“ (angl. New Quest), taip bandydamas atgaivinti istorinio Jėzaus svarbą krikščionių teologijai. Jo mokinys J. Jeremias, kuris nelabai bepritarè R. Bultmann'o mintims, 1960 m. tęsè šią protestantiškają tradiciją. Jo nuomone, tikroji Naujojo Testamento analizè turi būti istorinio Jèzaus kristologija. Nuo tada protestantų ir katalikų teologų dèmesys istoriniam Jèzui neprarado savo aktualumo iki šiandien. Dėmesio centre vèl atsirado Jėzaus pamokslai ir kiti ịvairūs jo viešojo gyvenimo aspektai: stebuklingi darbai, pamokymai, posakiai ir pan. Vis labiau gilinamasi į tai, kodèl buvo parašytos Evangelijos, kuo jos svarbios pirmajai krikščionių bendruomenei Jeruzaleje ir t. t.

Svarbu paminèti vadinamaji „trečią klausimą" (angl. Third Quest), kuri iškèlè E. P. Sanders'as 1985 m. publikuotoje knygoje „Jèzus ir judaizmas“. Šios naujos bangos biblinejje teologijoje esmè - siekis traktuoti Jèzų iš Nazareto judaizmo religijos ir kultūros kontekste, jo gimtojoje žmogiškoje istorinèje aplinkoje. Be to, Jėzaus skelbtoje kerigmoje bandyti ižzvelgti ryši tarp to meto politikos ir teologijos, ieškoti istorinių motyvų, kodèl iš tikrujų Jèzus buvo nukryžiuotas. Visa tai sukèlè entuziastingą naujų teologinių tyrinèjimų ir įžvalgu proveržị, iš esmès „,siekiant susieti krikščioniškają kerigmą su jos istoriniu kontekstu, kad ji būtų suprantamesnè visiems, netgi netikintiesiems" (Pie-Ninot, 2002, p. 333). Iš šios krypties teologų ir biblistų būtų galima paminèti vokiečius J. Gnilk'ą, R. Schnackenburg'ą ir H. Schurmann'ą. Apibendrinant bandymus analizuoti Jèzaus viešąi gyvenimą galima pasakyti, kad Jėzus skelbè ir savo pavyzdžiu rodè Dievo karalystės atėjimą visam Izraeliui. Karalystès atėjimo laukimą artimoje ateityje, kuri jau buvojo tarp Jėzaus klausytojų. Kadangi karalystès artẻjimo skelbimas apima ir atsivertimą, Jėzaus žinioje išryškejja eschatologinè ir etinè dimensijos. Jėzus 
nepadarè savęs savo mokymo centru. Vis dèlto žinia apie karalystès artèjimą neatsiejama nuo jo asmens - karalystė ateina per jo asmenį. Paties Jėzaus žodžiais tariant, jis yra pranašiška figūra, bet po Jo nebeįmanomas jokio kito pranašo atejimas. Taigi Jėzaus skelbiamos karalystès prielaidos yra kristologinès: ryšys tarp asmens ir žinios patvirtina, kad žinios tiesa neatskiriama nuo jo asmeninio tikslo. Galiausiai istoriniam Jèzui priskiriamos teologinès funkcijos skiriasi nuo apie jị turimų istorinių žinių.

Skirtinos trys pagrindinès pozicijos:

1. Kai kurie autoriai, kaip D. Strauss'as, neigè istorinio Jėzaus teologinę svarbą. Šiai ekstremaliai pozicijai teologai šiandien iš esmès nepritaria.

2. Kiti teologai, kaip R. Bultmann'as, siekdami pagrịsti tikèjimo ị Kristu faktą, teologiškai Kristaus nesiejo su istoriniu Jèzumi iš Nazareto. Taigi siekdamas numitinti Evangelijas autorius stengiasi atskirti povelykinès Bažnyčios tikẻjimą i Kristų nuo istorinio Jėzaus iš Nazareto. Verta pabrèžti, kad vargu ar R. Bultmann'as būtu galëjęs kalbèti apie kryžiaus skelbimą, jei Jèzus nebūtų buvęs iš tiesų, t. y. istoriškai, nukryžiuotas.

3. Daugelis žymiausių šiandienos teologų Jèzui priskiria teologinị aspektą ir reikšmę, tai sieja su mūsų istorinėmis žiniomis apie Jị.

Kardinolo W. Kasper'io teigimu, „kristologijos išeities taškas yra tikèjimo i Kristų reiškinys, kuris yra išgyvenamas, skelbiamas ir praktikuojamas. Tikèjimą į Kristų lemia susitikimas su krikščionimis, kurie ị Jị tiki. Originalus ir galutinis kristologijos turinys vis dèlto yra Jèzus Kristus, Jo gyvenimas, likimas, žodžiai ir darbai. Šia prasme galime teigti, kad Jèzus Kristus yra pirminis kristologijos kriterijus, o Bažnyčios tikèjimas Juo - antrinis“ (Kasper, 1989, p. 28-29).

\section{Jèzaus mirtis ir Poncijus Pilotas}

Kad suprastume geriau Poncijaus Piloto vaidmenį, būtina bent trumpam žvilgterèti ị Kristaus kančios istoriją, kuri gana ilga. „Hollywoodas“ yra sukūręs filmą „Kristaus kančia“, kur pamėginta detaliai parodyti paskutines 24 Jo gyvenimo valandas. Visos Evangelijos, esant kai kuriems niuansams, 
beveik sinchroniškai nupasakoja Jo kančią, mirtị ir prisikèlimą. Vienas išsamiausių pasakojimų yra Evangelijoje pagal Matą (Mt 26-28): pirmiausia Jėzus suimamas Alyvų sode, tada nuvedamas pas vyriausiajį kunigą Kajafą (aukščiausioji žydų religinè valdžia), kur išgirsta kaltinimą, tada jau vedamas pas Poncijų Pilotą, Romos imperatoriaus vietininką Palestinoje.

Pateikiame Jėzaus pokalbị su juo. „Surišę nuvedè ir atidavė jị valdytojui Pilotui““ (Mt 27, 2).

„Jėzus stovèjo valdytojo akivaizdoje. Valdytojas jị klausė: „Ar tu esi žydų karalius?“ Jèzus atsakè: „Taip yra, kaip sakai“. Aukštujjų kunigų ir seniūnų skundžiamas, jis visai neatsiliepė. Tuomet Pilotas paklausė: „Ar negirdi, kaip baisiai tave kaltina?" Bet jis neatsake nè ì vieną kaltinimą ir tuo be galo nustebino valdytoją. Šventès proga valdytojas buvo pratęs paleisti miniai vieną kalinį, kurio ji norèdavo. Tuomet jis turejjo garsų kalinį, vardu Barabas. Taigi, žmonėms susirinkus, Pilotas paklausė: „Katrą norite, kad jums paleisčiau: Barabą ar Jėzų, vadinamą Mesiju?" Mat jis žinojo, kad Jèzų jie buvo išdavę iš pavydo. Sėdinčiam teismo krasejje Pilotui žmona atsiuntė įspejimą: „Nieko nedaryk šiam teisiajam! Šiąnakt sapne aš labai dèl jo kentejjau.“ Aukštieji kunigai ir seniūnai sukurstè žmones, kad prašytų paleisti Barabą, o Jėzų pražudytų. Tuomet valdytojas jiems tarè: „Katrą norite, kad jums paleisčiau?“ Jie šaukè: „Barabą!“ Pilotas paklausè: „Ką gi man daryti su Jėzumi, kuris vadinamas Mesiju?“ Jie visi rèkè: „Ant kryžiaus jį!“ Jis klausė: „O ką gi pikta yra padaręs?“ Bet tie dar garsiau šaukè: „Ant kryžiaus jį!“” Pilotas, pamatęs, kad nieko nelaimi, o sąmyšis vis dideja, paèmè vandens, nusimazgojo rankas minios akivaizdoje ir tarè: „Aš nekaltas dèl šio teisiojo kraujo. Jūs žinokitė!““ O visi žmonės šaukė: „Jo kraujas [tekrinta] ant mūsų ir mūsų vaikų!“‘ Tuomet jis paleido jiems Barabą, o Jèzų nuplakdinęs atidavė nukryžiuoti“ (Mt 27, 11-27).

Šis pasakojimas nèra tikslus teismo protokolas. Tarkim, evangelistas Jonas yra gerokai daugiau išplètojęs šị susitikimą bei pokalbị, gvildenant Jèzaus karalystės ir Jo mirties priežastis (plg. Jn 18, 33-38). Tačiau visi Biblijos žinovai sutartinai pabrěžia - Jėzaus kančios ir mirties priežastis yra buvimas karaliumi. Pas Pilotą Jèzų atvedè todèl, kad pagal Romos imperijos jurisdikciją, žydų Sinedrijonas, aukščiausiasis jų teismas, neturèjo galios žmogų, kaltinamą šventvagyste, nuteisti mirties bausme, tad reikejo politinio kaltinimo. 
„Jèzus prisipažino esantis Mesijas, taigi pretendavo ị karaliaus titulą, nors ir visiškai savaip. Pretenduoti ị buvimą mesijiniu karaliumi reiškẻ politinị nusižengimą, už kurị persekiojo romėnų teisingumas“ (Ratzinger, 2011, p. 148).

Žvelgiant plačiau, t. y. tik kaip ị bet kurị kitą istorinị asmenį, Jėzaus mirties priežastis yra viso jo gyvenimo veikla. Nerami Kristaus viešojo gyvenimo atkarpa - tie treji metai - lèmé tragiškas jo gyvenimo pasekmes: jis skelbe savo karalystès žinią, kuri labai nepatiko to meto religinei ir politinei valdžiai, pelné liaudies palankumą, subūrẻ apie save sekèjų grupę, ypač dvylika mokinių, darè stebuklus, vadino Dievą savo Tèvu, kritikavo šventyklos kulto apeigas, konfrontavo su fariziejais ir pan. Todèl jo baigtis ir buvo tokia, kokia buvo. Jam, kaip niekam kitam, tinka posakis „mire taip, kaip ir gyveno“. Jeigu pabandytume teologiškai interpretuoti Jèzaus mirtį, pirštųsi mintis, kad Poncijus Pilotas savotiškai „vykdẻ Dievo valią“, nes Kristus mirè ant kryžiaus už mūsų nuodèmes, taip Dievas Jame parodė savo meilę žmogui iki galo ir jị išganè. Teologinių svarstymų objektas yra ne tiek pats nukryžiavimo faktas, kiek jo reikšmė, nes „mes skelbiame Jėzų nukryžiuotą, kuris žydams yra papiktinimas, pagonims - kvailystè. Bet pašauktiesiems - tiek žydams, tiek graikams - mes skelbiame Kristų, kuris yra Dievo galybė ir Dievo išmintis“ (1 Kor 1, 23-24). Apaštalas Paulius taikliai išreiškẻ šią mintį: ,Jis yra miręs už visus, kad gyvieji nebe sau gyventų, bet tam, kuris už juos numirè ir buvo prikeltas“ (2 Kor 5, 15). Ši mintis visada liks slëpinys - kiek buvo suteikta galimybe žmogaus laisvos valios pasirinkimams, o kiek Dievo buvo iš anksto numatyta visa šita istorija. Nei Pilotas, nei Kajafas neturèjo prielaidų ị Jị ịtikèti, nepanašu, kad šie asmenys būtų pradejję juo sekti. Nuostaba kelia žinia, kad Kristų suėmus pabėga net patys ištikimiausi apaštalai, išduoda Judas, išsigina Petras. Šių žingsnių motyvas: arba pats Jèzus turèjo padaryti kažką tokio, kad rimtai būtų Juo suabejota, atsiskleisti kaip apgavikas, melagis, arba mokiniai iki galo nesuprato nei Jo paties, nei Jo mokymo, todèl Juo nusivylè. Pasak J. Moltmann'o ir kitų teologų, Jėzaus mirtis iš tiesų glaudžiai siejasi su jo viešuoju gyvenimu: Jèzus norejo būti nukankintas ir visus savo veiksmus sąmoningai ị tai kreipè. Jo mirtị nulèmé atmetimas, o ne nesusipratimas. Žydų religijos vadovams Jèzaus požiūris ị i̊statymą buvo piktžodžiavimas ir kèlè rimtą pavojų jų pačių statusui. Mirtis 
buvo akivaizdus Jėzaus ištikimybės Evangelijos skelbimui rezultatas, suteikęs šiam skelbimui esminị pripažinimą (plg. Moltmann, 1991, p. 86-91). Biblisto B. F. Meyer'io teigimu, Jėzus suvokė mirtį kaip ,išperkamają aukąa už nuodèmes, kaip dangišką malonę nusidejjëliams. I klausimą, ar Jèzus suvokè, kad miršta už viso pasaulio nuodèmes, B. F. Meyer'is, remdamasis Biblija, atsako, kad jis tikrai turejo omenyje bent jau Izraelio tautą, kuri vèliau teologiškai ,prasiplètė“ iki visų tautų (plg. Meyer, 1992, p. 792).

Grịžkime prie istorinių duomenų analizès. Jėzuitų teologas J. Martin'as knygoje „Jèzus. Piligrimyste““ teigia, kad visgi tiek žydai - vyriausiasis kunigas Kajafas, Anas, jo uošvis (minimas tik Evangelijoje pagal Joną), tiek Poncijus Pilotas „bando savo manevrais atsakomybę už Jėzaus mirtị priversti prisiimti ką nors kitą. (...) Tačiau galiausiai už mirtị atsakingas tampa Pilotas, nes vienintelis asmuo, turintis galią pasmerkti žmogų mirties bausmei, buvo Romos vietininkas. (...) Jėzui buvo įvykdyta mirties bausme įsakius Poncijui Pilotui, bendradarbiaujant daliai žydų vadovybès iš Jeruzalès“" (Martin, 2016, p. 424-425).

Biblijos ir Artimujų Rytų istorijos žinovas Daniel'is R. Schwartz'as teigia, kad Pilotą gana dažnai savo raštuose mini Juozapas Flavijus, Tacitas ir Filonas iš Aleksandrijos, tačiau jų užuominos yra ne tiek susijusios su šio asmens biografija, kiek su to meto Judejos valdymu, ten kilusiais neramumais bei labai netiesiogiai su Kristaus mirties atveju. D. R. Schwartz'o teigimu, tai buvo penktasis Romos imperijos Judejos prokuratorius. Jo asmens istoriškumą, be Evangelijų ir minètų autorių, visu aiškumu patvirtina senovės mieste Cesarea Maritima 1961 m. atrastas archeologiniu požiūriu svarbus ịrašas, patvirtinantis, kad Pilotas tikrai valdè Judèją, bei įrašai ant išlikusių ano metų pinigų (plg. Schwartz, 1992, p. 398). Šiandien sutartinai manoma, kad apskritai dėmesys jo asmeniui būtų gerokai mažesnis, jei ne pirmujjų krikščionių dèmesys jam dèl Kristaus teismo.

Poncijus Pilotas eiti prokuratoriaus pareigas paskirtas $27 \mathrm{~m}$. po. Kr. Jo pirmtakas Valerijus Gratus valdè Judèją 11 metų. Pilotas Judejją valdè 10 metų, iki imperatoriaus Tiberijaus mirties $37 \mathrm{~m}$. kovo mèn. Žurnalistė Candida Moss šiais metais pasirodžiusiame įdomiame straipsnyje apie Pilotą, pavadinimu „Naujausi archeologiniai radiniai patvirtina, kad Pilotas nebuvo toks blogas, kaip manėme“, teigia, kad Poncijaus Piloto ịsakymu netoli Gerizimo kalno buvo nužudyta samariečių sukilèlių grupè. Po šio įvykio daugelis samariečių apskundè Poncijų Pilotą 
Sirijos legatui Vitelijui. Jis buvo iškviestas pasiaiškinti ị Romą, bet nespèjo susitikti su imperatoriumi Tiberiju, nes pastarasis mire jam dar neatvykus. Daugiau apie Poncijaus Piloto likimą nelabai kas ir žinoma. Tai chronologiškai sutampa su jo pareigu pabaiga - buvo suspenduotas. Krikščionių rašytojas Euzebijus iš Cezarèjos (IV a.) rašo, kad Pilotas gyvenimą užbaigè savižudybe, būdamas $39 \mathrm{~m}$. Tai patvirtinti ar paneigti yra sudètinga. Aišku viena - po šio iškvietimo ị Judèją nebegrį̌zo (plg. Moss, 2019). Panašus atvejis minimas Evangelijoje pagal Luką: „Tuo pačiu metu atejo keli žmonès ir papasakojo Jėzui apie galilëjiečius, kurių kraują Pilotas sumaišęes su jų aukomis“ (Lk 13, 1). Atšaukus Pilotą iš pareigų, keletą metų neskirtas joks valdytojas. Tik $44 \mathrm{~m}$. atvyko naujasis Judèjos prokuratorius Kuspijus Fadas (lot. Cuspius Fadus).

Poncijus Pilotas visgi rūpinosi kraštu. C. Moss teigimu, naujausi archeologiniai kasinejimai Jeruzalèje atskleidè, kad jo valdymo laikotarpiu Pilotas nutiesė grịstą kelią iš Jeruzalès šventyklos iki Siloamo tvenkinio, minimo Evangelijose, kur ateidavo daugelis sergančiųų pasigydyti. Prie to tvenkinio buvo ir Jėzus, stebuklingai pagydęs ligoni. Nèra tiksliai žinoma, kodẻl Pilotas tiesẻ ši kelią? Ar siekẻ padèti sergantiesiems, kad gydymosi tikslais tiesiai iš šventyklos lengviau nueitu iki stebuklingo tvenkinio, ar tiesiog gerindamas valdomo miesto infrastruktūrą, ar atvirkščiai - skatinamas noro įsiteikti aukštiesiems kunigams, nutiesè kelią nuo tvenkinio iki šventyklos, kad žmonès lengviau pasiektų šventovę. Archeologų teigimu, tai atskleidžia humaniškają Piloto asmens pusę. Iš esmès jis nebuvo tironas (plg. C. Moss, 2019). Visgi jo asmenybei būdingos dviprasmybès, pavyzdžiui, Filonas iš Aleksandrijos aprašo Poncijų Pilotą buvus kraugerišką vadovą, nuožmų biurokratą, piktnaudžiaujantị savo valdžia, negailestingą kaliniams ir nuteistiesiems (plg. Schwartz, 1992, p. 398). Bet kuriuo atveju Pilotas nesiskyrè nuo kitų tokio tipo valdytojų. Kaip minèta, visi teisiniai dalykai Judejjoje priklausè nuo Poncijaus Piloto, bet apie teismo procesą žinome tik iš Kristaus atvejo. Kitų duomenų neišlikę. Jo pareiga buvo ne tik nuteisti ar išteisinti, bet labiau rinkti mokesčius, tinkamai paskirstyti skiriamus pinigus provincijai iš imperijos biudžeto, teikti ataskaitas Romai (plg. Schwartz, 1992, p. 397). Panašu, kad Poncijus Pilotas turejo didelius ịgaliojimus, daug kur veike laisvai, jo „rankos buvo atrištos“. Tą liudija ir užuomina Evangelijoje pagal Joną, kur žydai vadina ji „Ciesoriaus draugu“ (Jn 19, 12). 
Yra žinoma, kad pirmaisiais amžiais buvo labai daug apokrifų, t. y. netikrų evangelijų, apie Jėzaus ir pirmujų krikščionių gyvenimą. Tarp jų yra ir vadinamieji „Piloto darbai“. Tačiau jie atrodo suklastoti, neatitinkantys istorinès chronologijos, moksliniu požiūriu traktuojami kaip visiškai nereikšmingas dalykas, tiesiog pasakos, pramanai. Šio Romos prokuratoriaus valdymo laikas buvo gana ramus, kiek gali būti apskritai ramus ano meto politinejje, religineje bei socialineje aplinkoje. Romos imperija tuo metu vykdè pirmąją ekspansiją i Germanų kraštus, tiesa, nesėkmingai. Tai vienaip arba kitaip paveikè visą imperiją, nes rinktos lěšos išlaikyti kariuomenę. Žydai jau nuo Makabiejų sukilimo laikų (200 m. pr. Kr.) nekentė okupantų, tad savaime suprantama, kad nemėgo ir romėnų. Verta paminèti, kad $70 \mathrm{~m}$. po Kr. imperijos generolas Titas visiškai užkariavo Jeruzalę, galutinai sugriovė šventyklą, sudegino miestą, pavergè tautą ilgiems šimtmečiams, kuri be savo valstybès išgyveno iki XX amžiaus vidurio, kai vèl buvo atkurta Izraelio valstybė. Neįtikètinas tautos gebejjimas viską išgyventi. Tada iš jos buvo atimta ,žemè, miestas ir šventykla“ (Ratzinger, 2011, p. 150).

Minint istorinius faktus, kurie susiję su Jėzaus teismu, galima teigti, kad Pilotas išties nebuvo iki galo ịsitikinęs Jo kaltumu, sąmoningai bandè išvengti Jị nuteisti mirties bausme, kitaip tariant, nuoširdžiai nenorejjo Kristaus mirties. Jo sprendimas nebuvo kaip žmogaus, turinčio laisvą valią daryti taip, kaip liepia sąžinè. Didžioji dalis atsakomybès tenka aukštiesiems žydų kunigams ir kitiems vadovams, spaudusiems Pilotą nuteisti Kristų. Jei nebūtų kilę žydų pasipiktinimo dèl viešosios Jèzaus veiklos, romėnų valdžia niekad nebūtų mirties bausme nuteisusi tokio veikejjo kaip Kristus, nes Jis Romos imperijai nekèlè jokios grèsmès (plg. Schwartz, 1992, p. 399). Pirmųjų amžių krikščionys manè taip pat: už Kristaus mirties įvykdymą iš esmès atsakinga žydų tauta. Poncijus Pilotas parodijuotame teismo procese buvo antraeilè figūra. Be to, toks autoritetingas krikščionių rašytojas kaip Tertulianas (lot. Tertullianus) teigè (II-III a. po Kr.), kad Poncijus Pilotas buvo įtikèjęs kai kuriomis krikščionybès tiesomis ir Jėzų laikè mažiausiai pranašu (plg. Schwartz, 1992, p. 400). Todèl šiandien Koptų ir Etiopijos krikščionių Bažnyčiose jis laikomas šventuoju. „Romos prefektas Evangelijose visiškai realistiškai rodomas kaip vyras, mokantis šiurkščiai įsikišti, jei to prireikia 
viešajai tvarkai palaikyti. Tačiau jis kartu supranta, jog Roma pasaulyje ịsiviešpatavo ir dẻl palankumo svetimoms dievybėms bei Romos teisès taiką steigiančios galią. Toks jis ir iškyla prieš mus Jėzaus teismo procese“ (Ratzinger, 2011, p. 152). Be to, J. Ratzinger'is pabrěžia, kad Poncijus Pilotas nerado nieko, kas būtų verta mirties bausmès. Religiniai dalykai Poncijaus Piloto nedomino, nes Jėzaus Karalyste buvo „ne iš šio pasaulio“, reiškia nesmurtinè. Kristus nekèlè jokios grèsmès imperijai. „Pilotą turèjo stebinti, kad Jèzaus tėvynainiai elgèsi kaip Romos gynèjai, kai, jo žiniomis, būtinybės ìsikišti nebuvo“" (Ratzinger, 2011, p. 152).

Poncijus Pilotas mėgina visaip Jėzų išteisinti ir pristato Jị Paschos amnestijai, manydamas, kad šia proga tikrai pavyks jị išgelbèti nuo mirties. Tačiau dar didesnei jo nuostabai, minia pasirenka nusikaltelį Barabą. Ji turèjo balsą skelbiant amnestiją. Tad Piloto padètis dar labiau komplikavosi. Galima teigti, kad šio teismo procese vienintelis Jėzaus šalininkas bebuvo pats Pilotas, kitu nebuvo: išsigando, išsilakstè, bijojo. Tai svarbi aplinkybe, leidžianti iš tiesų suvokti, kad nebuvo „,antro balso“, nebuvo to, kuris galètų palaikyti Jėzų. Vien tik kaltintojai. Pilotas prisibijojo Jèzaus. Gal šioje vietoje atsiskleidžia labai žmogiška ir kažkiek jo sąžinę prakalbinusi tiesa - Jèzus tikrai ne politinis maištininkas. Evangelijoje pagal Joną skaitome tokius žodžius: „Išgirdęs šiuos žodžius, Pilotas dar labiau nusigando“ (Jn 19, 8). Jie nuskambèjo iš žydų minios, kuri kaltino Kristų tuo, kad save laikè Dievo Sūnumi. „Tokie asmenys kaip Pilotas skaitèsi su dievų ar bent panašių būtybių pasirodymo žmogaus pavidalu galimybe“ (Ratzinger, 2011, p. 157). Taigi apskritai Poncijus Pilotas nebuvo tiesioginis ir pagrindinis Kristaus teisèjas. „Žydai nuteisė Jèzų mirties bausme dèl to, kad Jis dẻjosi Dievu, ir įžvelgè pavojų Jo sekẻjuose, kurie tariamai pažeidè İstatymą ir tradicijas“"(Lizzi Testa, 2007, p. 263).

\section{Išvados}

Žvelgiant teologiniu žvilgsniu, Kristaus mirtis buvo reikšminga, nes Jo kančia ir mirtis ant kryžiaus atvère duris ị amžinaji gyvenimą, džiaugsmą. Jo krauju įvykdytas atpirkimas suteikia tikintiesiems galimybę išvysti garbingą Dievo veidą. Mūsų mirtis yra nugalèta Kristaus mirties (Ciola, 2017, p. 168). 
Per Kristaus mirtị ir prisikèlimą tikintieji ịprasmina savo mirtị, kad vèl gyventų. Kristus puikiai suvokè, kad Jo skelbtoji žinia yra dovana žmonėms iš aukštybių, tai religinis lobis. Per Jo mirtị atleidžiamos nuodèmès, įvyksta Dievo ir žmonių sutaikinimas, vargas ịveiktas, mirties viešpatavimas sustabdytas. „Kristus savo mirti suvokẻ kaip savo gyvenimo dovanojimą Paskutinès vakarienès stalo bendrininkams: tai yra mažiausia, ką galima pasakyti. Mirdamas gana aiškiai suvokè, už ką miršta“ (Penna, 1999, p. 165). Šiuo požiūriu galime tvirtinti, kad ne tiek Kristaus įvykis yra didis istorinis ịvykis, kiek pati istorija tampa dideliu krikščionišku įvykiu. Šiandienos Biblijos ir dogminès kristologijos studijos remiasi istoriniais faktais. Naujausiuose Kristaus gyvenimo tyrinèjimuose bandoma žvelgti i visą Jo gyvenamojo laikotarpio kontekstą, ypač analizuojant judaizmo religiją ir kultūrą. Kristus visų pirma buvo žydas, taigi ir visa šios tautos kultūra bei tikejjimas turèjo įtakos Jo veiklai. Tačiau Jis, būdamas Dievo Sūnumi, peržengė konkrečios religijos ribas, nubrěždamas naujus horizontus ị Dievo karalystę, kuri pasireiškė jau nebe per İstatymą (Torah), bet Jo paties asmenyje.

$\mathrm{Su}$ istoriniu Jėzaus iš Nazareto asmeniu susiję daugybẻ kitų asmenų: imperatoriai, valdytojai, maištininkai ir pan. Ypač vertas dèmesio yra Poncijaus Piloto asmuo, nes tuo metu jis Judèjos regione buvo Romos imperijos prefektas, tiesiogiai atsakingas už politinès taikos palaikymą visame krašte. Evangelijos mini, kad teisiškai Poncijus Pilotas buvo atsakingas už Kristaus mirti, nes Romos imperijoje tik Romos vietininkas galèjo kažką nubausti tokia mirtimi. Tačiau Evangelijų ir istoriniai faktai byloja, kad toks vienpusis požiūris būtų pernelyg siauras. Nebuvo nei geresnis, nei blogesnis. Darè ir gerų darbų (tvarkė Jeruzalès infrastruktūrą, tiesẻ kelius, stengèsi užtikrinti taiką šioje imperijos provincijoje), kartu nuožmiai malšino sukilimus, baudẻ nusikaltèlius, saugojo savo pareigas, bendravo su imperatoriumi ir nuosekliai jam teikè ataskaitas apie esamą padètį. Yra išlikę net tariami imperatoriaus Klaudijaus laiškai apie tai, kad jis pasibaisejjo, kaip Poncijus Pilotas nekaltai nubaudė Kristų, „Dievo žmogų“, mirties bausme ir už tai skyrẻ jam griežtą nuobaudą. Bet šis tariamas tekstas datuojamas tik V amžiumi, taigi vẻlyvas ir nepatikimas, priskiriamas vadinamajai „Adajos doktrinai“, kuri iš esmès laikoma apokrifu (plg. Bettiolo, 2007, p. 1092). Taigi dèl Kristaus mirties 
buvo atsakingas ne vienas asmuo, pradedant vyriausiuoju kunigu Kajafu, jo uošviu Anu, vietiniu karaliumi Erodu, Sinedriju (Parlamentu), paprastais žydais, tautos seniūnais, be to, Judu Iskarijotu, netiesiogiai - ir Poncijumi Pilotu. Svarbų vaidmeni Kristaus teismo procese suvaidino paprastos, nepalankiai susiklosčiusios aplinkybès, kad teismo metu nebuvo nè vieno, kuris būtų palaikęs Jèzų. Buvo tik viena pusè, kuri žūtbūt norẻjo Jo mirties. Poncijus Pilotas, žvelgiant žmogišku žvilgsniu, vargu ar galèjo esant tokiai situacijai atsilaikyti ir pasielgti kitaip nei pasielgè. Jis negalèjo rizikuoti savo karjera dèl kažkokio niekam nežinomo, eilinio, kaip tuo metu atrodè, religinio maištininko. Poncijus Pilotas nusiuntė suimtą Jėzų pas vyriausiaji kunigą Kajafą, paskui pas Erodą, tada nuplakè, manydamas, kad to pakaks, paskui bandè taikyti Paschos amnestiją ir, didžiai jo paties nuostabai, visa tai nieko nereiškè. Minia šaukè: „Ant kryžiaus Jị “. Tada, ,nusiplovęs rankas, atidavė Jèzų nukryžiuoti““ (Mt 27, 24-25).

Poncijus Pilotas buvo šaltai mąstantis pragmatikas, puikiai suvokęs, kad Jėzus yra nekaltas teisiniu, (lot.) pax romana požiūriu. Kartu jis suvokè, kad „nekaltojo išteisinimas atneštų žalos ne tik jam asmeniškai - tokia baimė tikrai buvo lemiamas jo elgesio motyvas, - tai taip pat sukeltų dar didesni nepasitenkinimą ir neramumus, kurių Paschos dienomis kaip tik ir reikejjo išvengti“" (Ratzinger, 2011, p. 161). Jis stengèsi išlaikyti taiką ir taip manėsi nuraminsiąs savo sąžinę. Iš pirmo žvilgsnio tuo metu taip ir atrodè. Jeruzalès miestas per šventes liko ramus. Bet labai trumpam. To Poncijus Pilotas negalèjo ịžvelgti, kaip ir numatyti savo paties baigties, tad gal netiesiogiai šiuo požiūriu ir nepakaltinamas...

\section{Literatūra}

Bettiolo, P. (2007). Siria (I-VII secolo). Letteratura patristica. San Paolo, p. 1091-1113. Ciola, N. (2017). La rilevanza del nesso storia - fede per la cristologia. Alcuni punti fermi. Ricerca storica su Gesù. Bilanci e prospettive. Edizioni Dehoniane Bologna, p. 165-198.

Kasper, W. (1989). Gesu il Cristo. Brescia: Queriniana.

Lizzi Testa, R. (2007). Chiesa e impero. Letteratura patristica. San Paolo, p. 281.

Martin, J. (2016). Jèzus. Piligrimystè. Vilnius: katalikų pasaulio leidiniai.

Meyer, B. F. (1992). Jesus Christ. The Anchor Bible Dictionary, Vol. 3. New York: 
Doubleday, p. 773-796.

Moltmann, J. (1991). Trinita e Regno di Dio, La dottrina su Dio. Brescia: Queriniaina. Moss, C. New Archaeological Evidence Shows Pontius Pilate Not as Bad as We Thought. Prieiga internete: https://www.thedailybeast.com/pontius-pilate-not-as-bad-as-wethought-new-archaeological-evidence-triggers-reassessment [žiürèta 2019-12-17].

Penna, R. (1999). I ritratti originali di Gesu Il Cristo. Inizi e sviluppi delle cristologia neotestmentaria, II. Gli sviluppi. San Paolo.

Penna, R. (2004). Il DNR del cristianesimo. L'identita cristiana allo stato nascente. San Paolo.

Pie-Ninot, S. (2002). La teologia fondamentale. Brescia: Queriniana.

Ratzinger, J., Benediktas XVI. (2011). Jėzus iš Nazareto, Nuo įžengimo ị Jeruzalę iki prisikélimo. Vilnius: Katalikų pasaulio leidiniai.

Sanders, E. P. (1999). Istorinis Jèzaus asmuo. Kaunas: Šviesa.

Schwartz, D. R. (1992). Pontius Pilate. The Anchor Bible Dictionary, Vol. 5, New York: Doubleday, p. 395-401.

Šventasis Raštas. Senasis ir Naujasis Testamentas. (1998). Vilnius: Lietuvos Katalikų Vyskupų Konferencija.

FOLLOWING THE HISTORICAL JESUS:

THE CASE OF PONTIUS PILAT

\section{Arvydas Ramonas}

Summary

Historical Jesus of Nazareth has always been interested in Christians and non-Christians, atheists, and anyone interested in religion. In modern science, there is no doubt that such a person has lived historically. But the question of his historical context, his contact with Judaism, his true salvation intentions, remains open. Immediately after World War II, theological and biblical sciences focused on Jesus, Paul and other biblical characters. The historical Jesus is associated with the proclaimed and faithful Christ. The works of Karl Barth and Rudolf Bultmann of the Reformed Church appeared. According to K. Barth, we know about Christ only through faith. Meanwhile, 
R. Bultmann argued that we know almost nothing about Jesus' life and his person, so theology should focus not so much on Jesus' public historical life as on the proclamation of the cross, only at Christ's confession of the Easterly community of believers who atoned for mankind's sins. In the 1953, one of his lectures, Ernest Kasemann, a disciple of Bultmann, introduced the "New Quest" of historical Jesus in an attempt to revive the importance of historical Jesus for Christian theology. His apprentice, J. Jeremiah, who did not strongly agree with Mr Bultmann's ideas, went on to teach in 1960, continued this Protestant tradition. In his view, the true analysis of the New Testament must be the Christology of the historical Jesus. Since then, Protestant and Catholic theologians' attention to historical Jesus has not lost its relevance until today. Jesus' sermons and other aspects of his public life reappeared in the spotlight: miraculous works, teachings, sayings, and so on. There is a growing focus on why the Gospels were written, how important they are to the first Christian community in Jerusalem, and so on etc. It is important to mention the so-called "Third Quest", raised by E. Sanders in 1985, publishing the book "Jesus and Judaism". At the heart of this new wave in biblical theology is the aspiration to treat Jesus from Nazareth in Judaism in the context of religion and culture, in his native human historical environment. In addition, to try to discern the connection between the politics and theology of Jesus at the time of the proclamation of Jesus, to look for the historical reasons why Jesus was actually crucified. All this has led to an enthusiastic breakthrough in new theological explorations and insights, essentially in order to link Christian kerigma with its historical context to make it more understandable to everyone, even unbelievers.

In order to better understand the role of Pontius Pilate, it is necessary to take a brief look at the history of Christ's suffering. She is long enough. There are several versions of the trial in the Gospels. For example, Mt 27.11-27; John 18.33-38. Pontius Pilate was appointed in his duties in 27-th year AD. His predecessor Valerius Gratus ruled Judea for 11 years. Pilate ruled Judea for 10 years, until Emperor Tiberius died in 37 AD March. All the Jews Caiaphas the high priest, Ann, his father-in-law (only mentioned in the Gospel according to John), and Pontius Pilate try to make someone else take 
responsibility for Jesus' death by their manoeuvres. But ultimately Pilate becomes responsible for the death, for the only person with the power to condemn a man to death was a Roman deputy. Jesus was executed at the behest of Pontius Pilate, in collaboration with a section of Jewish leadership from Jerusalem. As for the historical facts concerning the trial of Jesus, Pilate was certainly not definitively convinced of His guilt, deliberately avoiding being sentenced to death, in other words, sincerely not wanting the death of Christ. His decision was not like a man with complete free will at that time to do as the conscience would command. Much of the responsibility lies with the Jewish high priests and other leaders who put great pressure on Pilate to convict Christ. Had it not been for the resentment of the Jews over Jesus' public activities, the Roman authorities would never have condemned a person like Christ to the death penalty. He posed no threat to the Roman Empire.

The Gospels mention that Pontius Pilate was legally responsible for the death of Christ, because only the Roman deputy in the Roman Empire could punish someone with such death. However, the deeper Gospel and historical evidence suggests that such a one-sided approach would be too narrow. The Pilot was no different from any other similar locals in, say, Spain or Galia. He was neither better nor worse. He did some good deeds (maintaining Jerusalem's infrastructure, building roads, striving for peace in this province of the empire), but at the same time fiercely suppressing insurgencies, punishing criminals, protecting his office, communicating with the emperor, and reporting consistently to the emperor. Even the alleged letters from the Emperor Claudius that the Emperor was appalled at Pilate's innocent punishment of Christ, the "man of God", were executed and punished Pontius severely. But this supposed text is only dated to the $\mathrm{V}$ century, so very late and unreliable, attributed to the so-called "Doctrine of Adaya", which is basically considered an apocryphal.

The Pilot was a cold pragmatist. He was well aware that Jesus was innocent from a legal, pax romana point of view. But he also realized that justifying the innocent would not only harm him personally - such fear was certainly the decisive motive for his behavior - it would also lead to even more frustration and turmoil that had to be avoided in Pascha days. He was trying to keep the peace, and so he thought to calm his conscience. At first glance, 
that was what it looked like at the time. The city of Jerusalem remained calm during the holidays. But for a very short time. Pilate could not see it, so indirectly in this sense he was not to blame... The very simple, unfavourable circumstance that there was no one to support Jesus during the trial played a very important role in Christ's trial. There was only one side who desperately wanted His death. From a human perspective, the pilot could hardly stand up to the situation and act differently than he did. He could not risk his career for something unknown to anyone, a regular religious insurgent at the time. For these reasons, Pilate is considered a saint in the Coptic and Ethiopian Christian churches today. The Roman prefect is shown in the Gospels in a very realistic way as a man who can learn to intervene severely when it comes to public order. At the same time, however, he understands that Rome has reigned in the world for the sake of alien deities and the peace-making power of Roman law. Such is the case with us in the trial of Jesus. 